\title{
Hubungan Karakteristik Morfofisiologi Tanaman Kersen (Muntingia Calabura)
}

\author{
(Relationship Morphophysiology of Muntingia calabura) \\ Nurholis $^{1 *}$ dan Ismail Saleh ${ }^{2}$ \\ ${ }^{1}$ Program Studi Agroteknologi, Fakultas Pertanian, Universitas Trunojoyo Madura, \\ Jl. Raya Telang PO. BOX. 2 Kamal, Bangkalan, Madura \\ ${ }^{2}$ Program Studi Agroteknologi, Fakultas Pertanian, Universitas Swadaya Gunung Jati, \\ Jl. Pemuda No. 32 Cirebon, Jawa Barat, 45132 \\ *Email Korespondensi: nurholis@trunojoyo.ac.id
}

Diterima 18 Juni 2019/Disetujui 03 September 2019

\begin{abstract}
Muntingia calabura is one of an underultilized plants that has not been used optimally. This plant can be used as medicinal plants due to metabolite content in its leaves and fruit. The purpose of this research was to identified the charactheristic of leaves, flower, and fruit of Muntingia calabura. Sample of Muntingia trees was taken from five locations in Cirebon and Kuningan, West Java with different elevation. The locations i.e., Pilang (4 meters above sea level ( $m$ asl)), Bima (15 m asl), Gronggong (135 $\mathrm{m}$ asl), Cilimus (476 $\mathrm{m}$ asl), and Cigugur $(960 \mathrm{~m}$ asl). The research was conducted from November 2015 until March 2016. The result showed that Muntingia's leaves was single blade type with length and wide of leaves were $10.67 \mathrm{~cm}$ and $4 \mathrm{~cm}$, respectively. Flower of Muntingia had white petal and green sepal. Immature Muntingia fruit were green and the mature fruit was red. The weight of fruit was about $1.71 \mathrm{~g}$. Vitamin C content of waterleaf was $2.31 \mathrm{mg} / \mathrm{g}$ fresh weight and the sweetnes (total soluble solid) was $19.14 \%$ Brix. Based on correlation analysis, leaf area positively correlated with ovary diameter and fresh weight of fruit. Fresh weight of fruit negatively correlated with total soluble solid of fruit.
\end{abstract}

Keywords: characterization, total soluble solid, vitamin C

\section{ABSTRAK}

Kersen (Muntingia calabura) merupakan salah satu tumbuhan liar yang belum dimanfaatkan secara optimal. Tumbuhan ini dapat dimanfaatkan sebagai tanaman obat dengan memanfaatkan daun atau buahnya. Penelitian ini bertujuan untuk mengidentifikasi karakteristik morfologi dan fisiologi daun, bunga, dan buah kersen. Penelitian dilakukan dengan mengambil sampel tanaman kersen di wilayah Cirebon dan Kuningan, Jawa Barat dengan ketinggian tempat yang berbeda. Lokasi pengambilan sampel tanaman kersen yaitu Pilang (4 mdpl), Bima (15 mdpl), Gronggong (135 mdpl), Cilimus (476 mdpl), dan Cigugur (960 mdpl).Penelitian dilaksanakan pada bulan November 2015 - Maret 2016. Hasil pengamatan menunjukkan bahwa daun kersen memiliki karakteristik berdaun tunggal dengan panjang dan lebar daun berturut-turut 10.67 cm dan $4 \mathrm{~cm}$. Bunga kersen termasuk ke dalam bunga sempurna dengan mahkota berwarna putih dan kelopak berwarna hijau. Buah kersen berbentuk bulat dan ketika muda berwarna hijau dan merah ketika sudah matang. Bobot buah kersen yang sudah matang berkisar $1.71 \mathrm{~g}$. Kadar vitamin C buah kersen berkisar $2.31 \mathrm{mg} / \mathrm{g}$ bobot basah dan tingkat kemanisan (padatan total terlarut) buah kersen yaitu $19.14 \%$ Brix. Berdasarkan hasil analisis korelasi, luas daun berkorelasi positif dengan diameter ovari dan bobot buah. Bobot buah kersen berkorelasi negatif dengan tingkat kemanisan buah.

Kata Kunci: karakterisasi, padatan total terlarut, vitamin C

\section{PENDAHULUAN}

Indonesia merupakan salah satu wilayah tropis yang memiliki keanekaragaman flora. Peluang pengembangan tanaman yang berkhasiat obat terus dilakukan. Salah satu kendala dalam pengembangan tanaman obat adalah ketersediaan bahan yang terbatas, serta budidaya yang dilakukan belum intensif. Salah satu tumbuhan yang berpotensi untuk dikembangkan sebagai tanaman obat adalah tanaman kersen (Muntingia calabura). Kersen merupakan spesies tunggal dari Muntingia. Pemanfaatan buah kersen masih belum optimal karena dianggap tidak memiliki nilai ekonomis serta kurangnya pengetahuan mengenai pemanfaatannya (Yunahara et al., 2009).

Tumbuhan kersen merupakan tumbuhan liar yang banyak ditemukan di pinggir jalan dan seringkali digunakan sebagai peneduh. Kersen merupakan salah satu tumbuhan yang sangat potensial untuk dimanfaatkan karena daun dan 
buah dari tanaman ini memiliki beberapa kandungan bioaktif yang bermanfaat untuk kesehatan. Beberapa penelitian sebelumnya menunjukkan bahwa tanaman kersen mengandung beberapa senyawa bioaktif seperti saponin, flavonoid, dan tanin (Surjowardojo et al., 2014; Kolar et al., 2011) yang dapat sebagai antimikroba, antioksidan, antibakteri dan antifungal (Siddiqua et al., 2010; Kolar et al., 2011; Sibi et al., 2012; Sufian et al., 2013; Surjowardojo et al., 2014). Kandungan tersebut juga memiliki fungsi sebagai antioksidan yang dapat mereduksi radikal bebas (Yunahara et al., 2009)

Bagian tanaman yang dapat digunakan sebagai obat antara lain daun dan buah. Buah kersen selain dapat digunakan untuk bahan baku olahan makanan, dapat juga digunakan sebagai bahan baku obat karena memiliki karakteristik sebagai antioksidan (Preethy et al., 2010). Kandungan dari buah kersen antara lain squalene, trigliserida, campuran antara asam linoleate, asam palmitat, dan asam $\alpha$ linoleat dan campuran $\beta$ sitosterol dan stigmasterol (Ragasa et al., 2015). Kadar karbohidrat buah kersen lebih rendah dibandingkan dengan daun dan sebaliknya kadar protein buah kersen lebih tinggi dibandingkan dengan yang terdapat pada daun (Krishnaveni dan Dhanalakshmi, 2014).

Karakteristik morfologi dan fisiologi buah sebagai organ generatif dipengaruhi oleh organ tanaman yang lain seperti daun. Daun merupakan organ tanaman tempat berlangsungnya fotosintesis. Tujuan dari penelitian ini adalah untuk mengidentifikasi karakteristik morfologi dan fisiologi daun, bunga, dan buah kersen serta keterkaitan antara ketiganya.

\section{BAHAN DAN METODE}

Pengamatan karakteristik tanaman kersen dilakukan pada bulan November 2015 sampai Maret 2016. Sampel pohon kersen diambil dari lima lokasi di Kabupaten Kuningan dan Cirebon dengan ketinggian tempat yang berbeda-beda. Dari setiap lokasi diambil tiga sampel pohon kersen secara acak dan masing-masing pohon diambil 10 daun, bunga, dan buah yang sudah matang untuk dianalisis. Lokasi dan ketinggian tempat pengambilan sampel dapat dilihat pada Tabel 1.Daun kersen yang diamati diambil secara acak dengan kriteria daun telah dewasa (posisi di tengah cabang). Bunga yang diamati adalah bunga yang sudah mekar sempurna dan belum mengalami penyerbukan. Buah yang diamati adalah buah yang sudah matang yang ditandai dengan warna kemerahan.

Pengamatan dilakukan dengan melakukan uji korelasi antara karakteristik morfologi daun dengan karakteristik bunga dan buah yang dihasilkan. Karakteristik morfologi daun meliputi panjang daun, lebar daun, dan luas daun. Karakterstik bunga meliputi panjang, lebar, dan jumlah petal (mahkota bunga), panjang dan jumlah sepal (kelopak bunga), panjang putik dan diameter ovary. Sedangkan karakteristik buah yang diamati meliputi panjang, diameter, dan bobot buah, serta panjang petiol (tangkai buah), kadar air buah, kemanisan buah (\% Brix) dan vitamin $\mathrm{C}$ buah kersen (metode titrimetri). Pengamatan penunjang antara lain tipe dan filotaksi daun kersen, kadar flavonoid daun kersen, serta bobot biji per buah kersen.

\section{HASIL DAN PEMBAHASAN}

\section{Bentuk Daun Kersen}

Berdasarkan Glimn-Lacy dan Kaufman (2006), tipe daun kersen termasuk tipe daun Dicot. Tipe daun ini memiliki tulang daun yang menyirip. Vena daun menyebar dari vena utama yang terletak di bagian tengah (Gambar 1).

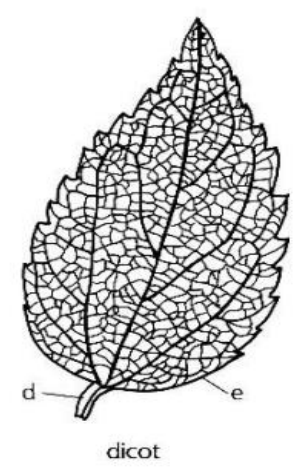

Gambar 1. Tipe Daun Kersen

Daun kersen memiliki permukaan daun yang kesat, memiliki rambut daun dan memiliki ukuran daun 1-4 x 4-14 $\mathrm{cm}$. Daun kersen memiliki keunikan yaitu sisi daun satu dengan yang lainnya tidak simetris (sisi helai daun lebih panjang dari sisi yang lainnya). Tempat melekatnya daun kersen (leaf attachment) termasuk ke dalam tipe petiolateyaitu leaf blade menempel pada batang oleh petiol. Bentuk daun kersen termasuk ke dalam tipe simple yaitu satu daun memiliki satu leaf blade (Heyne, 1987).

\section{Karakteristik Morfologi Daun, Bunga, dan Buah Kersen}

Berdasarkan hasil pengamatan, rata-rata panjang daun kersen yaitu $10.67 \mathrm{~cm}$, lebar $4.0 \mathrm{~cm}$ dan luas daun $30.63 \mathrm{~cm}^{2}$. Data panjang, lebar, dan luas daun kersen dari beberapa lokasi dapat dilihat pada Tabel 2.

Bunga kersen muncul dari ketiak daun kersen. Bunga kersen yang telah mekar memiliki mahkota bunga berwarna putih dan kelopak bunga berwarna hijau. Bunga tanaman kersen merupakan bunga sempurna. Anther berwarna kuning. Bunga tumbuhan kersen terletak pada satu berkas yang letaknya supra-aksilar dari daun bersifat hemaprodit. karakteristik bunga tanaman kersen dapat dilihat pada Tabel 3.

Buah kersen berbentuk bulat, ketika masih muda berwarna hijau dan berwarna merah ketika sudah matang. Tangkai buah berwarna hijau dengan panjang rata-rata 2.6 $\mathrm{cm}$. Biji kersen berukuran kecil dan berjumlah ratusan di dalam satu buah kersen. Buahnya mempunyai tipe buah buni, berwarna merah kusam bila masak, dengan diameter 1125 , berisi beberapa ribu biji yang kecil, terkubur dalam 
daging buah yang lembut. Rata-rata bobot biji kersen adalah $0.079 \mathrm{~g} \mathrm{buah}^{-1}$. Karakteristik buah kersen dapat dilihat pada Tabel 4.

Rata-rata panjang buah kersen yang sudah matang berkisar $1.34 \mathrm{~cm}$ dengan rata-rata diameter $1.47 \mathrm{~cm}$ dan ratarata bobot buah $1.71 \mathrm{~g}$. Hasil penelitian Rahman et al., (2010) menunjukkan bahwa diameter buah kersen yang sudah siap panen sekitar $1.17 \mathrm{~cm}$ dan panjang $1 \mathrm{~cm}$. sedangkan bobotnya kurang lebih $1.42 \mathrm{~g} \mathrm{buah}^{-1}$ dan memiliki padatan total terlarut $10 \%$ Brix

\section{Karakteristik Fisiologi Daun dan Buah Kersen}

Kadar flavonoid daun kersen setara quersetin diamati pada tiga lokasi yaitu Pilang (dataran rendah), Cilimus (dataran menengah), dan Cigugur (dataran tinggi). kadar flavonoid daun kersen pada masing-masing lokasi tersebut ditunjukkan pada Tabel 5.

Tabel 1. Lokasi pengambilan sampel pohon kersen

\begin{tabular}{clc}
\hline No & \multicolumn{1}{c}{ Lokasi } & Ketinggian Tempat \\
\hline 1 & Cigugur (Kab. Kuningan) & $960 \mathrm{~m} \mathrm{dpl}$ \\
2 & Cilimus (Kab. Kuningan) & $476 \mathrm{~m} \mathrm{dpl}$ \\
3 & Gronggong (Kab. Cirebon) & $135 \mathrm{~m} \mathrm{dpl}$ \\
4 & Bima (Kota Cirebon) & $15 \mathrm{~m} \mathrm{dpl}$ \\
5 & Pilang (Kota Cirebon) & $4 \mathrm{~m} \mathrm{dpl}$ \\
\hline
\end{tabular}

Keterangan: $\mathrm{m} \mathrm{dpl} \mathrm{:} \mathrm{meter} \mathrm{di} \mathrm{atas} \mathrm{permukaan} \mathrm{laut}$

Tabel 2. Panjang, lebar, dan luas daun kersen dari beberapa lokasi

\begin{tabular}{lrccccccc}
\hline \multicolumn{1}{c}{ Lokasi } & Panjang Daun $(\mathrm{cm})$ & \multicolumn{2}{c}{ Lebar Daun $(\mathrm{cm})$} & \multicolumn{3}{c}{ Luas per Daun $\left(\mathrm{cm}^{2}\right)$} \\
\hline Pilang & $9.79 \pm 0.69$ & $3.74 \pm$ & 0.39 & 25.29 & \pm \\
Bima & 10.16 & \pm 0.30 & $3.92 \pm$ & 0.15 & 3.69 & \pm .12 & \pm \\
Gronggong & 9.26 & \pm 0.29 & $3.23 \pm$ & 0.13 & 19.72 & \pm & 1.64 \\
Cilimus & 10.70 & \pm 0.14 & $4.01 \pm \pm$ & 0.12 & 30.22 & \pm \\
Cigugur & 13.42 & \pm 0.39 & $5.10 \pm$ & 0.24 & 47.81 & \pm & 3.74 \\
\hline
\end{tabular}

Keterangan: angka diikuti oleh \pm standar error.

Tabel 3. Karakteristik morfologi bunga kersen

\begin{tabular}{|c|c|c|c|c|c|c|c|c|c|c|c|c|c|c|c|}
\hline \multirow{2}{*}{$\begin{array}{l}\text { Lokasi } \\
\text { Pilang }\end{array}$} & \multicolumn{3}{|c|}{$\begin{array}{l}\text { Panjang Petal } \\
(\mathrm{cm})\end{array}$} & \multicolumn{3}{|c|}{ Lebar Petal $(\mathrm{cm})$} & \multicolumn{3}{|c|}{$\begin{array}{c}\text { Panjang Sepal } \\
(\mathrm{cm})\end{array}$} & \multicolumn{3}{|c|}{$\begin{array}{l}\text { Diameter Ovary } \\
(\mathrm{cm})\end{array}$} & \multicolumn{3}{|c|}{ Panjang Putik $(\mathrm{cm})$} \\
\hline & 1.09 & \pm & 0.01 & 0.82 & \pm & 0.03 & 1.16 & \pm & 0.03 & 0.31 & \pm & 0.00 & 0.65 & \pm & 0.00 \\
\hline Bima & 1.04 & \pm & 0.01 & 0.76 & \pm & 0.06 & 1.12 & \pm & 0.02 & 0.30 & \pm & 0.00 & 0.60 & \pm & 0.01 \\
\hline Gronggong & 0.90 & \pm & 0.01 & 0.64 & \pm & 0.05 & 1.03 & \pm & 0.01 & 0.27 & \pm & 0.00 & 0.61 & \pm & 0.01 \\
\hline Cilimus & 0.96 & \pm & 0.02 & 0.77 & \pm & 0.05 & 1.02 & \pm & 0.01 & 0.29 & \pm & 0.01 & 0.61 & \pm & 0.01 \\
\hline Cigugur & 0.99 & \pm & 0.01 & 0.82 & \pm & 0.03 & 1.04 & \pm & 0.01 & 0.33 & \pm & 0.00 & 0.56 & \pm & 0.01 \\
\hline
\end{tabular}

Keterangan: angka diikuti oleh \pm standar error.

Tabel 4. Karakteristik morfologi buah kersen

\begin{tabular}{|c|c|c|c|c|c|c|c|c|c|}
\hline \multirow{2}{*}{$\begin{array}{l}\text { Lokasi } \\
\text { Pilang }\end{array}$} & \multicolumn{3}{|c|}{ Panjang Buah (cm) } & \multicolumn{3}{|c|}{ Diameter Buah (cm) } & \multicolumn{3}{|c|}{ Bobot Buah (g) } \\
\hline & 1.35 & \pm & 0.03 & 1.51 & \pm & 0.02 & 1.65 & \pm & 0.03 \\
\hline Bima & 1.45 & \pm & 0.03 & 1.50 & \pm & 0.02 & 1.75 & \pm & 0.11 \\
\hline Gronggong & 1.19 & \pm & 0.01 & 1.29 & \pm & 0.03 & 1.40 & \pm & 0.09 \\
\hline Cilimus & 1.29 & \pm & 0.03 & 1.53 & \pm & 0.03 & 1.86 & \pm & 0.04 \\
\hline Cigugur & 1.29 & \pm & 0.03 & 1.55 & \pm & 0.04 & 1.90 & \pm & 0.06 \\
\hline
\end{tabular}

Keterangan: angka diikuti oleh \pm standar error. 
Tabel 5. Kadar flavonoid daun kersen

\begin{tabular}{ccc}
\hline Aksesi & Kadar Flavonoid Setara Quersetin $(\%)$ \\
\hline Pilang & $2.05 \pm 0.06$ \\
Cilimus & $2.14 \pm 0.02$ \\
Cigugur & $2.33 \pm 0.01$ \\
\hline
\end{tabular}

Keterangan: angka diikuti oleh \pm standar error.

Tabel 6. Kadar air, kemanisan, dan kadar vitamin $\mathrm{C}$ buah kersen

\begin{tabular}{|c|c|c|c|c|c|c|c|c|c|}
\hline Aksesi & \multicolumn{3}{|c|}{ Kadar Air (\%) } & \multicolumn{3}{|c|}{ Kemanisan (\% Brix) } & \multicolumn{3}{|c|}{ Vitamin $\mathrm{C}(\mathrm{mg} / \mathrm{g} \mathrm{BB})$} \\
\hline Pilang & 77.98 & \pm & 0.55 & 19.40 & \pm & 1.44 & 2.40 & \pm & 0.51 \\
\hline Bima & 76.78 & \pm & 0.59 & 20.27 & \pm & 0.61 & 2.38 & \pm & 0.40 \\
\hline Gronggong & 77.76 & \pm & 0.66 & 20.77 & \pm & 0.91 & 1.82 & \pm & 0.48 \\
\hline Cilimus & 80.33 & \pm & 0.80 & 18.60 & \pm & 1.40 & 2.12 & \pm & 0.30 \\
\hline Cigugur & 80.59 & \pm & 0.17 & 16.67 & \pm & 1.30 & 2.85 & \pm & 0.11 \\
\hline
\end{tabular}

Keterangan: angka diikuti oleh \pm standar error.

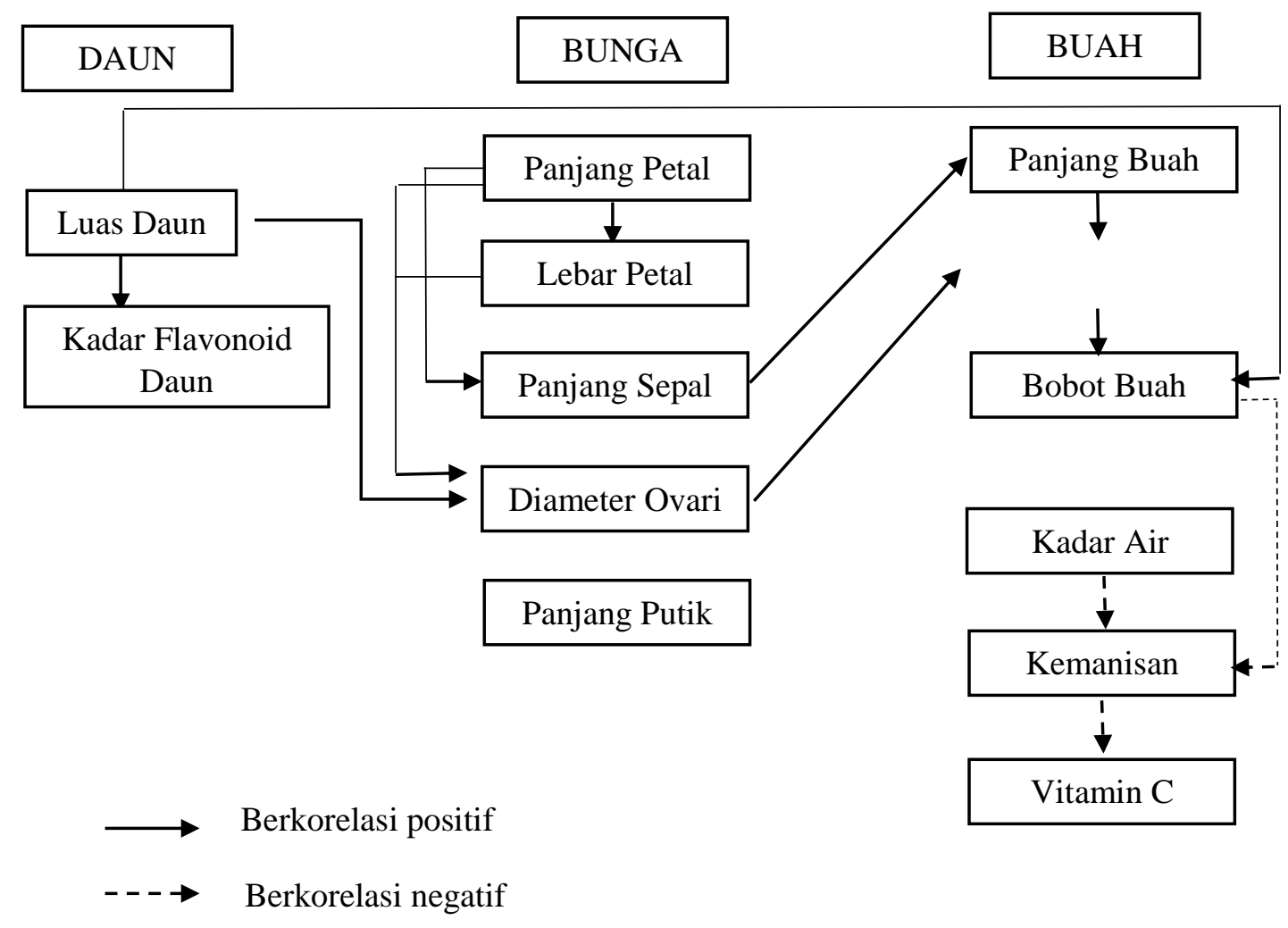

Gambar 2. Analisis korelasi antara karakteristik daun, bunga, dan buah kersen

Kadar flavonoid daun kersen pada daerah cigugur yang merupakan dataran tinggi $(960 \mathrm{~m} \mathrm{dpl})$ mengandung kadar flavonoid daun yang lebih tinggi sebesar $0.004 \%$ sampai $0.005 \%$ jika dibandingkan dengan kadar flavonoid dari dataran rendah $(4 \mathrm{~m} \mathrm{dpl})$ dan dataran sedang (476 m dpl). Menurut Mintowati et al. (2013), aktivitas antioksidan daun kersen tua lebih tinggi dibandingkan daun muda, dan semakin tinggi kandungan flavonoidnya maka potensi antioksidannya semakin tinggi. Hasil penelitian Kubola et al., (2011) menunjukkan bahwa buah kersen mengandung flavonoid sebesar $0.02-28.51 \mathrm{mg} \mathrm{g}^{-1}$ sampel kering dan jenis flavonoid pada buah kersen adalah rutin, myricetin, luteolin, quercetin, apigenin, dan kaempferol.

Kadar air, kemanisan, dan kadar vitamin $\mathrm{C}$ buah kersen ditunjukkan pada Tabel 6. Rata-rata kadar air yang sudah matang yaitu $78.8 \%$. Tingkat kemanisan buah kersen 
yang diukur berdasarkan padatan total terlarut (PTT) yaitu $19.14 \%$ Brix dan rata-rata kadar vitamin $C$ yaitu $2.31 \mathrm{mg} \mathrm{g}^{-1}$ bobot basah (BB). PTT buah kersen pada penelitian ini lebih tinggi dibandingkan dengan hasil penelitian Rahman, Fakir, \& Rahman (2010) yang menunjukkan kadar PTT 10\% Brix. Menurut Kubola et al. (2011) dan Gomathi et al. (2013) buah kersen memiliki komponen bioaktif yang berpotensi sebagai sumber antioksidan karena kandungan vitamin $\mathrm{C}$ yang tinggi yaitu sebesar $33.6 \mathrm{mg} \mathrm{AAE} \mathrm{g}^{-1}$ dinyatakan dalam mg Ascorbic Acid Equevalents atau sebesar 3.36\% buah kersen. Selain memiliki vitamin $\mathrm{C}$ yang tinggi buah kersen mengandung kadar flavonoid dinyatakan dalam $\mathrm{mg}$ Myricetin Equivalents per satu gram berat kering yaitu 1.8421.80 $\mathrm{ME} \mathrm{g}^{-1}$.

Kadar Air dan kandungan vitamin $\mathrm{C}$ buah kersen pada aksesi atau daerah cigugur (960 m dpl) memiliki kadar air buah yang lebih tinggi sebesar $0.21 \%$ sampai $2.91 \%$ dan kandungan vitamin $\mathrm{C}$ buah sebesar $0.01 \%$ sampai $0.02 \%$ jika dibandingkan dengan berbagai aksesi lainnya. Kemanisan buah kersen pada aksesi atau daerah gronggong (135 m dpl) mempunyai kemanisan buah yang lebih tinggi sebesar $0.11 \%$ sampai $0,68 \%$ jika dibandingkan kemanisan buah dari berbagai aksesi lainnya.

\section{Analisis Korelasi Antara Karakteristik Daun, Bunga, dan Buah Tanaman Kersen}

Analisis korelasi antara beberapa karakteristik morfologi dan fisiologi pada daun, bunga, dan buah kersen dapat dilihat pada Gambar 2.

Berdasarkan analisis korelasi tersebut dapat dilihat bahwa terdapat beberapa hubungan antara karakteristik daun, bunga, dan buah kersen. Luas daun kersen berkorelasi positif dengan kadar flavonoid daun kersen. Luas daun tersebut juga berkorelasi positif dengan diameter ovary dan bobot buah kersen. Menurut Gardner et al. (2008) daun merupakan tempat produksi karbohidrat bagi tanaman budidaya. Daun diperlukan untuk penyerapan dan pengubahan energi cahaya melalui proses fotosintesis sehingga dapat menjadi source bagi tanaman yang nantinya akan digunakan untuk proses pertumbuhan dan perkembangan terutama pada sink atau bagian tanaman yang menggunakan asimilat (buah). Selanjutnya Salisbury dan Ross (1995) menyatakan bahwa peningkatan bobot buah menunjukkan adanya dukungan hasil dan transportasi fotosintat ke daerah organ tersebut. Hal tersebut menunjukkan bahwa tanaman kersen yang memiliki daun yang lebih luas juga diikuti dengan peningkatan bobot buah kersen yang dihasilkannya. Diameter ovary berkorelasi positif dengan diameter buah yang dihasilkan. Sedangkan panjang sepal berkorelasi positif dengan panjang buah. Pembentukan buah pada buah normal dimulai dengan adanya proses polinasi dan fertilisasi. Buah terbentuk dari bakal buah (ovari) yang akan membesar dan berkembang menjadi buah bersamaan dengan pembentukan biji (Pardal 2001; Jamsari et al., 2007; Putri dan Pramono, 2013). Menurut Setiawan (2015), buah merupakan hasil perkembangan bakal buah (ovari) yang mengalami spesialisasi sebagai suatu bejana tempat biji berada. Bagi tumbuhan buah berfungsi untuk melindungi biji, membantu penyebarannya dan kadang-kadang juga merupakan faktor yang menentukan dalam perkecambahannya.

Tingkat kemanisan buah kersen berkorelasi negatif dengan bobot buah, kadar air, serta kadar vitamin $\mathrm{C}$ dari buah kersen. Hal tersebut menunjukkan bahwa peningkatan bobot buah kersen diikuti dengan penurunan tingkat kemanisan dari buah tersebut. Semakin besar kadar air dari buah kersen, maka kemanisan dari buah tersebut semakin berkurang. Hasil penelitian Atmaja et al. (2016) tingkat kemanisan jambu biji menurun diduga disebabkan karena peningkatan kadar air. Kandungan vitamin $\mathrm{C}$ pada buah kersen cenderung menurun seiring dengan bertambahnya tingkat kemanisan pada buah. Umumnya selama pematangan, kadar asam organik berkurang karena diubah menjadi glukosa. Kadar asam organik mencapai maksimum pada fase pertumbuhan dan perkembangan, kemudian menurun pada fase pematangan atau maturasi. Menurut Winarno (2002), buah yang masih mentah banyak mengandung vitamin $\mathrm{C}$ tetapi, semakin tua buah maka kandungan vitamin $\mathrm{C}$ semakin berkurang. Selama pematangan biasanya asam-asam organik menurun karena menjadi substrat respirasi atau dikonversi menjadi gula.

\section{KESIMPULAN}

Berdasarkan hasil pengamatan diperoleh data karakteristik kersen sebagai berikut:

1. Daun buah kersen merupakan daun tunggal yang memiliki panjang $10.67 \mathrm{~cm}$ dan lebar $4 \mathrm{~cm}$. Daun kersen memiliki trikoma (bulu daun) di permukaan daunnya.

2. Bunga kersen merupakan bunga sempurna dengan mahkota bunga berwarna putih dan kelopak bunga berwana hijau. Benang sari berjumlah banyak dengan kepala sari berwarna kuning.

3. Buah kersen memiliki diameter $1.17 \mathrm{~cm}$, bobot buah $1.71 \mathrm{~g}$ dengan tingkat kemanisan $19.14 \%$ Brix dan kadar vitamin $\mathrm{C}$ buah yaitu $2.33 \mathrm{mg} \mathrm{g}^{-1}$ bobot buah segar.

4. Terdapat keterkaitan antara karakteristik daun, bunga, dan buah tanaman kersen. Luas daun berkorelasi positif dengan bobot buah kersen. Sedangkan bobot buah kersen berkorelasi negatif dengan tingkat kemanisan buah.

\section{DAFTAR PUSTAKA}

Atmaja, I. S., I. Saleh, R. Eviyati, D. Budirokhman. 2016. Kajian aplikasi pupuk kandang dan pupuk NPK terhadap kualitas dan mutu jambu biji merah (Psidium guajava L.) kultivar getas pada musim kemarau. Agrovigor, 9(2), 111-117.

Gardner, F. P., R.B. Pearce, R.L. Mitchell. 2008. Fisiologi Tanaman Budidaya. (S.H. Subiyanto, Penerj.) Jakarta: UI Press. 
Glimn-Lacy, J., P.B. Kaufman. 2006. Botany Ilustrated (2nd ed.). New York: Springer.

Gomathi, R., N. Anusuya, S. Manian. 2013. A dietary antioxidant suplementation of Jamaican cherries (Muntingia calabura L) attenuates inflammatory related disorders. Food Sci. Biotechnol., 22(3), 787794.

Heyne, K. 1987. Tumbuhan Berguna Indonesia. Jakarta: Badan Litbang Kehutanan Jakarta.

Jamsari, Yaswendri, M. Kasim. 2007. Fenologi perkembangan bunga dan buah spesies uncaria gambir. Biodiversitas, 8(2), 141-146.

Kolar, F. R., V.S. Kamble, G.B. Dixit. 2011. Phytochemical constituents and antioxidant potential of some underused fruits. African Journal of Pharmacy and Pharmacology, 5(18), 2067-2072.

Krishnaveni, M., R. Dhanalakshmi. 2014. Qualitative and quantitaive study of phytochemicals in Muntingia calabura L. leaf and fruit. World Journal of Pharmaceutical Research, 3(6), 1687-1696.

Kubola, J., M. Siriamornpun. M. Naret. 2011. Phytochemicals, vitamin $\mathrm{C}$ and sugar content of Thai Wild Fruit. Food Chemistry, 126, 972-981.

Mintowati, E., Kuntorini, Setya, Maria. 2013. Struktur anatomi dan uji aktivitas antioksidan ekstrak metanol daun kersen (Muntingia calabura). Semirata FMIPA Universitas Lampung. Bandar Lampung: FMIPA Universitas Lampung.

Pardal, S.J. 2001. Pembentukan buah partenokarpi melalui rekayasa genetika. Buletin AgroBio, 4(2), 45-49.

Preethy, K.N., R. Vijayalakshmi, R. Shamna, J.M. Sasikumar. 2010. In vitro antioxidant activity of extracts from fruits of Muntingia calabura Linn. from India. Phogg J., 2(14), 11-14.

Putri, K.P., A.A. Pramono. 2013. Perkembangan bunga, buah, dan keberhasilan reproduksi jenis saga
Adenanthera pavonina. Jurnal Penelitian Hutan Tanaman, 10(3), 147-154.

Ragasa, C.Y., M.C. Tan, D. Chiong, C. Shen. 2015. Chemical constituents of Muntingia calabura L. Der Pharma Chemica, 7(5), 136-141.

Rahman, M. M., M.S. Fakir, M.M. Rahman. 2010. Fruit growth of China cherry (Muntingia calabura). Botany Research International, 3(2), 56-60.

Salisbury, F. B., C.W. Ross. 1995. Fisiologi Tumbuhan. (S. Lukman, Penerj.) Bandung: ITB.

Setiawan, E. 2015. Perkembangbiakan Tanaman. Bangkalan: UTM Press.

Sibi, G., Naveen, R., Dhananjaya, K., Ravikumar, K. R., \& Mallesha, H. (2012). Potential use of Muntingia calabura L. extract against human and plant pathogens. Phcog J., 4(34), 44-47.

Siddiqua, A., K.B. Premakumari, R. Sultana, Vithya, Savitha. 2010. Antioxidant activity and estimation of total phenolic content of Muntingia calabura by colorimetry. International Journal of Chem. Tech. Research., 2(1), 205-208.

Sufian, A. S., N. Ramasamy, N. Ahmat, Z.A. Zakaria, M. Izwan, M. Yusof. 2013. Isolation and identification of antibacterial and cytotoxic compounds from the leaves of Muntingia calabura L. Journal of Ethnopharmacology, 146, 198-204.

Surjowardojo, P., I. Sarwiyono, Thohari, A. Ridhowi. 2014. Quantitative and qualitative phytochemicals analysis of Muntingia calabura. Journal of Biology, Agriculture and Healthcare, 4(16), 84-88.

Winarno, F. G. 2002. Kimia Pangan dan Gizi. Jakarta: PT Gramedia Pustaka Utama.

Yunahara, F., S. Setyorini, L.S. Witha. 2009. Uji aktivitas antioksidan pada buah talok dengan metode DPPH dan Rancimat. Seminar PATPI (hal. 9-16). Jakarta: Fakultas Farmasi Universitas Pancasila. 